\title{
KONFLIK BATIN TOKOH UTAMA DALAM NOVEL AKU LUPA BAHWA AKU PEREMPUAN KARYA IHSAN ABDUL QUDDUS TINJAUAN KRITIK SASTRA FEMINISME
}

\author{
Indah Ika Ratnawati \\ UNIVERSITAS BALIKPAPAN \\ Jl. Pupuk Raya, Gn. Bahagia, Balikpapan, Kalimantan Timur \\ Email: ikaindah093@gmail.com
}

\begin{abstract}
Abstrak
Analisis psikologi sastra tidak bisa terlepas dari kebutuhan-kebutuhan masyarakat.Karya sastra memberikan pemahaman terhadap masyarakat secara tidak langsung.Karena dengan melalui pemahaman terhadap tokoh-tokohnya, masyarakat dapat memahami perubahan, kontradiksi, dan penyimpangan-penyimpangan lain yang terjadi dalam masyarakat, khususnya segala masalah yang terkait dengan psike.konflik batin yaitu suatu pertarungan individual melawan dirinya sendiri. Dalam konflik ini timbul kekuatan-kekuatan yang saling bertentangan dalam batin seseorang, keberanian melawan ketakutan, kejujuran melawan kecurangan, kekikiran melawan kedermawanan, dan sebagainya.Tujuan dalam penelitian untuk mengetahui kepribadian yang dimiliki Tokoh Utama dalam novel Aku Lupa Bahwa Aku Perempuan karya Ihsan Abdul Quddus.

Dalam penelitian ini digunakan metode penelitian kualiatif deskriptif. Metode penelitian kualitatif merupakan prosedur penelitian yang menghasilkan data deskriptif berupa kata-kata tertulis atau lisan tentang sifat suatu individu, keadaan, atau gejala dari kelompok tertentu yang dapat diamati.

Dari analisis konflik batin tokoh utama mengalami pertarungan individu melawan dirinya sendiri. Di mana tokoh Suad lebih perpengangan teguh untuk mempertahankan Egonya di banding Id yang sebenarnya di dalam hati kecilnya Suad sangat membutuhkan Idnya terpenuhi.Karena Suad inggin menjadi seorang pemimpin perempuan yang di kenal di public. Sehingga Ego Suad lebih kuat dan mengalahkan Idnya kebutuhan pribadinya bahkan Ego Suad mengenyampingkan Superego di mana Superego tersebut yang ada kaitanya dengan sikap moral dan sosial kepada orang lain.
\end{abstract}

Kata Kunci: konflik batin, id, ego, dan superego

\section{Pendahuluan}

Penelitian sastra terus berkembang dari waktu ke waktu.Pendekatan yang digunakan untuk meneliti karya sastra juga semakin beragam.Penelitian terhadap karya sastra tidak lagi hanya tertuju pada unsur-unsur intrinsik, tetapi telah meluas mencakup unsur-unsur ekstrinsik. Dari segi ekstrinsik, implementasi penelitian karya sastra telah bersinergi dengan disiplin ilmu lain. Salah satu cabang ilmu yang ikut memperkaya khazanah penelitian sastra adalah ilmu psikologi, khususnya psikoanalisis yang dipelopori oleh Sigmund Freud.

Sampai saat ini teori yang paling banyak diacu dalam pendekatan psikologis adalah determinisme psikologi Singmund Freud (1856-1939).Menurutnya, semua gejala yang bersifat mental bersifat tak sadar yang tertutup oleh alam kesadaran (Scellenberg dalam Ratna, 2004: 62). Dengan adannya ketak seimbangan, maka ketaksadaran menimbulkan dorongan-dorongan yang 
pada gilirannya memerlukan kenikmatan yang disebut libido. Meskipun demikian, teori kepribadian menurut frued pada umumnnya dibagi menjadi tiga, yaitu: a. id atau Es, b) ego atau Ich, c) Super Ego atau Uber Ich. Isis Id adalah dorongan-dorongan primitive yang harus dipuaskan, salah satunya adalah libido di atas.Id dengan demikan merupakan kenyataan subjektif primer, dunia batin sebelum individu memiliki pengalaman tentang dunia luar.Ego bertugas untuk mengontrol Id, sedangkan Super Ego berisi kata hati.

Analisis psikologi sastra tidak bisa terlepas dari kebutuhan-kebutuhan masyarakat.Karya sastra memberikan pemahaman terhadap masyarakat secara tidak langsung.Karena dengan melalui pemahaman terhadap tokoh-tokohnya, masyarakat dapat memahami perubahan, kontradiksi, dan penyimpangan-penyimpangan lain yang terjadi dalam masyarakat, khususnya segala masalah yang terkait dengan psike dan tujuan analisis adalah unsur-unsur kejiwaan yang terkandung dalam karya sastra.Inilah yang mendorong penulis untuk memilih novel Aku Lupa Bahwa Aku Perempuan karya Ihsan Abdul Quddus, seorang pengarang dari Negara Mesir.Aku Lupa Bahwa Aku Perempuanmengisahkan seorang perempuan yang bernama Suad yang telah menggapai ambisinya.Sebagai politis sukses, kiprahnnya diparlemen dan pelbagai organisasi pergerakan perempuan menempatkan dirinya dalam lingkar elit kekuasaan.Latar belakang politik yang masih konservatif kala itu menjadikan fenomena baru dalam isu kesadaran gender.

Tetapi, kehampaan menyelimuti kehidupan pribadinnya dan hampir membuat jiwanya tercerabut.Masalah-masalah mendera, bahkan anak semata wayangnya yang dia anggap sebagai harta paling berharga justru lebih akrab dengan ibu tiri dan dia selalu gagal dalam membangun rumah tangga bersama kedua suaminya, laki-laki yang dia anggap mau menikahinya ternyata tidak kunjung datang dan melamarnya. Hingga suatu kala, ia memutuskan lari dari kehidupan pribadinnya. Pada usia lima puluh lima tahun, ia melakukan apa saja untuk melupakan bahwa ia adalah perempuan. Inilah novel luar biasa tentang pergulatan karier, ambisi dan cinta.Kaya muatan filsafat tetapi dikemas dalam bahasa sederhana dan mengesankan. Tuntutan kesetaraan gender yang dirajut dalam kisah pertentangan batin seorang perempuan.

Pemilihan novel Aku Lupa Bahwa Aku Perempuan Karya Ihsan AbdulQuddus sebagai objekpenelitian penulis adalah karena:

1. Novel Aku Lupa Bahwa Aku Perempuan Karya Ihsan Abdul Quddus banyak bercerita tentang pergulatan karier, ambisi dan cinta. Tuntutan kesetaran gender yang dirajut dalam kisah pertentangan batin seorang perempuan.

2. Novel Aku Lupa Bahwa Aku Perempuan Karya Ihsan Abdul Quddus lebih banyak dan variatifmengungkapkan konflik batin tokoh utama dalam novel yaitu Suad

3. Selain itu, apa yang menjadi pokok persoalan atau permasalahan dalam novel Aku Lupa Bahwa Aku Perempuan Karya Ihsan Abdul Quddus adalah bagaimana konflik batin tokoh utama, 
terjadinya solusi yang dipakai tokoh utama untuk mengatasi konflik batinnya tersebut serta seperti apa kepribadian tokoh utama tadi. Untuk menjawab pertanyaan tersebut, masalah yang berkaitan dengan Konflik Batin Tokoh Utama dalam Novel Aku Lupa Bahwa Aku Perempuan Karya Ihsan Abdul Quddus, tentunya tidak bisa dilepaskan dari konteks psikoanalisis dan problem kehidupan manusia dewasa ini.

Berdasarkan alasan itulah penulis memilih Novel Aku Lupa Bahwa Aku Perempuan Karya Ihsan Abdul Quddus, karya Ihsan Abdul Quddus sebagai objek penelitian. Berdasarkan penelitian ini diharapkan dapat diketahui persoalan-persoalan yang dihadapi manusia dewasa ini dan solusi yang perlu dilakukan.

\section{Metode}

Jenis penelitian ini termasuk ke dalam penelitian psikologi sastra karena penelitian ini meneliti mengenai aktivitas konflik batin yang terdapat dalam teks novel Aku Lupa Bahwa Perempuankarya Ihsan Abdul Quddus.Penelitian ini juga termasuk ke dalam jenis penelitian feminisme yang meneliti perempuan sebagai tokoh utama dalam novel tersebut memfokuskan pada tokoh utama yang dilihat dari refleksi aktivitas-aktivitas konflik batin yang dialaminnya di dalam kehidupan tokoh utama. Metode penelitian merupakan hal esensial dalam suatu penelitian. Dalam penelitian ini hal-hal yang harus ditempuh adalah sebagai berikut:

\section{a. Objek Penelitian}

Objek Penelitian ini adalah makna konflik batin tokoh utama yang terdapat novel $A k u$ Bahwa Lupa Aku Perempuan karya Ihsan Abdul Quddus.

\section{b. Data dan Sumber Data \\ 1. Data}

Data penelitian sastra adalah bahan penelitian atau lebih tepatnya bahan jadi penelitian yang terdapat dalam karya sastra yang akan diteliti (Sangidu. 2004: 61). Wujud data dalam penelitian berupa kata, frase, dan kalimat yang terdapat dalam novel Aku Lupa Bahwa Aku Perempuan karya Ihsan Abdul Quddus.

\section{Sumber Data}

Sumber data yang digunakan dalam penelitian ini adalah sumber data kepustakaan yaitu berupa buku, transkrip, majalah, dan lain-lain.Sumber data ini adalah Konflik Batin Novel $A k u$ Lupa Bahwa Aku Perempuan karya Ihsan Abdul Quddus.Diterbitkan oleh Pustaka Alvabet, tahun terbit 2012 dengan tebal $228 \mathrm{hlm} .13$ x $20 \mathrm{~cm}$. 


\section{c. Teknik Pengumpulan Data}

Pengumpulan data dalam penelitian diperoleh dari sumber data. Adapun metode yang digunakan adalah metode pustaka yaitu mencari data mengenai hal-hal berupa buku teks, buku referensi, surat kabar, dan sebagainya (Arikunto, 1989: 188). Karena data yang didapat berbentuk tulisan, maka harus dibaca, disimak, dan dicatat, dan kemudian dijadikan acuan dalam hubungnnya dengan subjek yang akan diteliti. Data yang dikumpulkan adalah deskriptif kualitatif yaitu pengumpulan data yang berupa kata-kata, gambar, dan bukan angka-angka (Maleong, 1984: 7)

Teknik pengumpulan data yang dilakukan dalam penelitian adalah dengan mendata semua kata-kata, kalimat ataupun dialong tentang dari tokoh utama yang terdapat dalam novel Aku Lupa Bahwa Aku Perempuan karya Ihsan Abdul Quddus.

Secara rinci teknik pengumpulan data dapat dilakukan dengan:

1. Melakukan pembacaan terhadap novel Aku Lupa Bahwa Aku Perempuan karya Ihsan Abdul Quddus secara cermat dan teliti.

2. Melakukan pendataan terhadap dialog-dialog dan paragraph yang terdapat dalam novel $A k u$ Lupa Bahwa Aku Perempuan karya Ihsan Abdul Quddus.

3. Setelah dialog dan paragraf didata, kemudian dicari kata-kata atau kalimat yang termasuk ke dalam konflik batin dalam novel Aku Lupa Bahwa Aku Perempuan karya Ihsan Abdul Quddus.

\section{d. Teknik Analisis Data}

Penelitian ini menggunakan teknik kualitatif deskriptif. Menurut Satoto (1991: 15), analisis kualitatif dapat digolongkan ke dalam metode deskriptif yang penerapanya bersifat menuturkan, memaparkan, memberikan, menganalisis, dan menafsirkan.

Proses analisis data diawali dua langkah pemahaman maka yang dilakukan secara heuristic dan hermeneutic atau retroaktif. Pembacaan heuristic juga dapat dilakukan secara structural (Pradopo dalam Sangidu 2004: 19).Artinya pada tahap ini pembaca dapat menemukan arti (meaning) secara linguistic. Selanjutnya langkah kedua pembacaan hermenutik merupakan cara kerja yang dilakukan pembaca dengan pembaca dengan kerja secara terus menerus lewat bacaan teks sastra secara bolak balik dari awal sampai akhir. Dengan pembacaan bolak-balik itu, pembaca dapat mengingat peristiwa-peristiwa atau kejadian-kejadian tersebut antara yang satu dengan lainnya sampai dapat menemukan makna karya sastra pada system sastra yang tertinggi, yaitu makna keseluruhan teks sastra sebagai system tanda (Riffaterre dan Culler dalam Sangidu, 2004: 19).

Pembacaan heuristic ataupun pembacaan hermeneutic dapat berjalan secara serentak bersama-sama. Akan tetapi secara teoritis sesuai dengan metode ilmiah untuk mempermudah 
pemahaman dalam proses pemaknaan dapat dianalisis secara bertahap dan sistematis yaitu pertama kali dilakukan pembacaan hermeneutic (Sangidu, 2004: 19-20).

\section{Pembahasan}

Bentuk konflik dibedakan menjadi dua kategori, yaitu konflik fisik dan konflik batin, konflik internal dan konflik eksternal.Konflik eksternal adalah konflik yang terjadi antara seorang tokoh dengan sesuatu yang diluar dirinya. Konflik internal atau konflik batin adalah konflik yang terjadi dalam hati, jiwa seorang tokoh atau tokoh-tokoh cerita yang diakibatkan oleh adanya pertentangan antara dua keinginan, keyakinan, pilihan yang berbeda, harapan-harapan, atau masal-masalah lain. Konflik meruapakan bagian terpenting dari alur suatu cerita. Berdasarkan hal-hal di atas, maka pada bab IV, dipaparkan mengenai konflik batin pada tokoh utama yang terdapat dalam novel Aku Lupa Bahwa Aku Perempuan karya Ihsan Abdul Qudus.

\section{Konfik Batin Yang Disebabkan Oleh Keyakinan}

Keyakinan yang dimiliki Suad membuat diri Suad menjadi perempuan sukses sesuai apa yang dicita-citakan. Suad mampu menjadikan dirinya menjadi perempuan sukses salah satunya menjadi anggota Dewan Perwakilan Rakyat, Ketua Asosiasi Wanita Karir, Sekertaris Ikatan Putri Arab.Sehingga Ego yang yang terdapat pada diri Suad hilang, karena Id pada diri Suad sangat kuat untuk menjadikan dirinya perempuan sukses.Hal tersebut dapat dilihat pada kutipan di bawah ini.

Sekali-sekali aku terperanjat oleh keadaan.Keadaan jenuh dan sempit.Padahal aku begitu yakin, akulah perempuan sukses yang berhasil mewujudkan setiap cita dan kehendak diri hingga aku mampu menjadikan diriku seperti sekarang ini.Kini aku adalah salah satu anggota Dewan Perwakilan Rakyat (DPR), Ketua Asosiasi Wanita Karier (AWK), Sekretaris Ikatan Putri Arab (IPA) dan masih banyak.(hal. 1)

Aku menyediakan dua hari dalam seminggu bagi Abdul Hamid untuk mengunjungi rumahku.Hari senin untuk minum teh bersama dan hari kamis makan malam dirumahku. Lima hari lebihnya tidak ada hal - hal lain yang kuperbolehkan menggangu konsentrasiku mempersiapkan diri menghadapi ujian akhir, termask Abdul Hamid. Sebelum kesepakatan dua hari itu, Abdul Hamid bisa datang kerumahku setiap hari meski tidak ada kesepakatan apapun antara kami untuk merenda hubungan.Mungkin karena dia sedemikian yakin telah bisa membaca logika dan perasaan ku. (hal. 23)

Berdasarkan kutipan di atas, Ego pada diri Suad, dia membuat kesepatakan kepada Abdul Hamid melakukan pertemuan sesuai dengan jadwal yang sudah ditentukan oleh Suad. Hari senin minum teh bersama, hari kamis makan malam dirumah Suad.Lima hari lainya tidak boleh 
mengaggu konsentrasi Suad untuk belajar mengahadapi Ujian akhir.Tetapi Abdul Hamid bisa datang kerumah Suad setiap hari, meskipun tidak ada kesepakatan dengan suad.Karena Abdul Hamid percaya dan yakin telah bisa membaca logika dan perasaan Suad (Ego).

\section{Konflik Batin Yang disebabkan oleh Pilihan}

Berdasarkan kutipan di bawah ini, bahwa Id yang dimiliki Suad sejak lahir membuat dirinya menjadi perempuan yang cerdas, cantik, dan perempuan berprestasi. Suad merasa bahwa pilihan yang diambil sejak dini bukan sesungguhnya pilihan keingginanya untuk menjadi perempuan cerdas, pintar dan cantik. Karena pilihan itu bersebrangan dengan tabiat Suad secara pribadi.

Aku memilih jalan hidup ini sejak dini usiaku.Sesungguhnya pilihan ini bukanlah keinginanku, bukan hasil studiku dan bukan pula hasil ekprementasi dalam hidupku.Pilihan ini bersebrangan dengan tabiatku berlawanan dengan kepribadian yang kubawa sejak lahir.Pilihan ini adalah prestasi.Prestasi yang bukan pembawaanku-atau setidaknya-bukan pilihan setiap perempuan manapun.Ini adalah pilihan prestasi yang bukan kehendak naluri dan kebutuhan keputrianku. Dan bukan pula kehendak kecerdasan dan kecantikan.(hal. 4-5)

\section{Konflik Batin Yang Disebabkan Oleh Harapan}

Tanpa disadari oleh Suad ternyata Abdul Hamid sudah berdiri di depan pintu dan berjalan mendekati Suad. Setengah berbisik Abdul Hamid berkata untuk menikah dengan Suad, sebenarnya Suad sudah lama mengharapkan kata-kata seperti itu.Kata-kata yang sudah dipilih oleh Abdul Hamid membuat Id Suad terpenuhi.Hal tersebut dapat dilihat pada kutipan di bawah ini.

Kamarku terbuka. Tiba - tiba Abdul Hamid sudah berdiri di depan pintu dan berjalan mendekatiku di meja belajar. Setengah berbisik, dia membuka keheningan, " suad, bagaimana kalau kita menikah?"

Telah lama aku mengharapkan dia membuka pembicaraan tentang pernikahan kami dan hari ini dia mengatakannya.Dalam hati kecil, aku bahagia dan tidak terkejut karenanya.Tetapi kata - kata yang dia pilih telah menciptakan suasana kaget bagiku, apalagi dia masuk ke kamarku saat aku masih mengenakan pakaian tidur, pakaian resmiku untuk belajar. (hal 24)

Sesaat kami saling diam. Pandangan mata kami bertaut. Kami melemparkan perasaan masing masing kepada yang lain, seakan sama - sama membuat prediksi gerangan apa yang akan terjadi. Masih setengah berbisik hingga hampir tak terdengar, dia bertanya,"bagaiman"?aku menggelengkan kepala dengan jawaban "ya" yang sengaja ku sembunyikan. Sesaat aku termenung dan tiba - tiba aku ingin meralat gelengan kepalaku, " Maksudku, kita tunda pembicaraan ini sampai aku selesai ujian skripsi." (hal 24)

Berdasarkan kutipan di atas, Sesat Suad dan Abdul Hamid diam pandangan mata mereka melemparkan perasaan masing-masing kepada yang lain seakan-akan membuat prediksi gerakan apa yang akan apa yang akan terjadi (Ego). Setengah berbisik Abdul Hamid bertanya kepada Suad tentang pernikahan, Suad menjawab dengan gelengan kepala.Setelah termenung sesaat Ego Suad 
ingin meralat gelengan kepala tadi.Karena merasa Id Suad tidak terpenuhi.Dengan memperjelas kepada Abdul Hamid bahwa pembicaraan itu ditunda sampai Suad selesai ujian skripsi.

\section{Konflik Batin Yang Disebabkan Oleh Masalah}

Masalah terbesar yang kurasakan pada awal masa - masa perkawinan kami adalah tentang masakan dan makanan.Bukan karena aku tidak punya waktu untuk memasak, melainkan karena aku tidak pandai memasak dan tidak ingin pandai memasak.Suatu waktu aku mempunyai ide untuk menyediakan satu hari dalam seminggu untuk kami makan di rumah ibuku dan satu hari kami makan di rumah mertuaku.Tetapi kenyataannya kami makan di rumah ibuku bukan hanya sehari melainkan dua hari dalam seminggu. Hari - hari sisanya aku pulang kerumah dan mempersiapkan sendiri makanan untuk suamiku dengan bantuan Ummu Zakiyah. (hal. 47)

Berdasarkan kutipan di atas, Masalah terbesar di awal pernikahan Suad dengan Abdul Hamid ketika Suad tidak mau pandai memasak untuk Abdul Hamid. Suatu saat Ego Suad berpendapat satu hari makan dirumah ibu Suad satu berikutnya makan dirumah mertuanya. Tetapi, kenyataanya Suad dan Abdul Hamid dirumah ibunya tidak hanya sehari tetapi seminggu.Hari-hari sisanya Suad pulang kerumah dan menyiapkan makanan untuk Abdul Hamid. Dengan demkian dapat disimpulkan bahwa konflik batin meliputi beberapa kejadian dalam kehidupan tokoh utama di antaranya.

\section{Kesimpulan}

1. Konflik Batin Disebabkan Oleh Keyakinan

Keyakinan yang dimiliki Suad membuat dirinya selalu bertahan terhadap prinsipnya.Bahwa semua logika (Ego) Suad selalu merasa benar dan tepat.Sehingga konflik batin yang dialami Suad membuat dirinya tidak pernah melaksanakan Superego di dalam masyrakat.

2. Konflik Batin Disebabkan Oleh Pilihan

Pilihan hidup tokoh Suad membuat dirinya tidak terpenuhinya Id yang sebenarnya sangat dibutuhkan oleh Suad.Di mana Suad lebih memilih Ego yang menurut logikanya lebih membuat dirinya menjadi seorang pemimpin perempuan.Tetapi pilihan Suad membuat dirinya menjadi perang batin dengan dirinya sendiri, yang sebenarnya dia membutuhkan Idnya terpenuhi.

3. Konflik Batin Disebabkan Oleh Harapan

Harapan Suad untuk dicintai suami dan memiliki anak sepenuhnya membuat perang batin Suad.Di mana Ego Suad berfikiran bahwa karier dan ambisi menjadi prioritas utama dalam hidup Suad.Tetapi tidak dipungkiri Id Suad membutukan kehadiran suami dan anaknya di dalam hidupnya.Di mana suami dan anaknya meninggalkanya, karena mereka merasa tidak diperhatikan oleh Suad. 
4. Konflik Batin Disebabkan Oleh Masalah

Masalah-masalah yang terjadi dalam kehidupan Suad membuat dirinya menjadi seorang perempuan kuat dan tangguh.Meskipun selalu terjadi perang batin dirinya dengan masalah yang menghapirinya. Masalah itu muncul disebabkan Suad mengutakan pekerjaan (Ego) dibandingah melayani suami dan menjadi seorang ibu dari Faizah anaknya (Id)

\section{Daftar Rujukan}

Alwisol. 2010. Psikologi Kepribadian. Malang: UMM Pres.

Aminuddin, dkk.2004. Sekitar Masalah Sastra Beberapa Prinsip dan Model Pengembanganya. Malang: Yayasan Asih Asah Asuh Malang.

Freud, Sigmand. 2006. Psikonalisis Editor dan penerjemah K. Bartens. Jakarta: PT Gramedia Pustaka Utama.

Jarvis, Matt. 2000. Teori-Teori Psikologi. Terjemahan oleh: SPA-Teamwork. Bandung: Nusantara Media.

Moleong, Lexy J. 1984. Metode Penelitian Kualitatif. Bandung: PT Remaja Karya.

Nurgiyantoro, Burhan. 2009. Teori Pengkajian Fiksi. Yogyakarta: Gadjah Mada University Press.

Nugroho, Aryo Widhi. Konflik Batin Nathan Algren (Analisis Semiotik) dalam Filem The Last Sanuari. Jurnal.

Quddus, Abdul Ilham. 2010. Aku Lupa Bahwa Aku Perempuan. Jakarta: Pustaka Alvabet.

Ratna, Nyoman Kutha. 2010. Teori, Metode, dan Teknik Penelitian Sastra dari Strukturalisme Hingga Postruturalisme. Yogyakarta: Pustaka Pelajar.

Sutoto, Sudiro. 1991. Metode Penelitian Sastra. Jakarta: Gramedia.

Sangidu. 2004. Penelitian Sastra, Pendekatan Teori Sastra, Metode, Teknik. KIA. Yogyakarta: Unit Penerbitan Sastra Barat.

Siswantoro. 2004. Metode Penelitian Sastra Analisis Psikologi. Surakarta: Sebelas Maret University Press.

Stanton, Robert. 1984. Sastra dan Ilmu Sastra. Jakarta: PT. Pustaka Jaya.

Tarigan, Hendry Guntur. 1981. Prinsip-Prinsip Dasar Sastra. Bandung: Angkasa.

Wellek, Waren. 1990. Teori Kesustraan. Jakarta: PT Gramedia Pustaka Utama. 